Mariya Y. Omelicheva

Contemporary Politics 22(2): 144-163, 2016

\title{
Islam and Power Legitimation: Instrumentalisation of Religion in Central Asian States
}

\begin{abstract}
How can Islam play multiple and contradictory roles as a source of violence and peace, and a marker of identity differences and national unity? This study argues that religion, as a system of beliefs, manifests itself through discourses, which not only render intelligibility to religious practices and beliefs but also serve as the instruments of social control and regulation. An infinite variety of organizational and ideological differences within Islam presents the possibility for instrumentalisation of religion by stakeholders interested in accomplishing distinctive political aims connected to political legitimation. The study offers an empirical analysis of instrumentalisation of Islam by governments of Kazakhstan and Uzbekistan and uses this evidence for developing a framework linking various discursive representations of religion to their political uses.
\end{abstract}

Key words: Islam, instrumentalisation of religion, Kazakhstan, Uzbekistan 9982 words 
Mariya Y. Omelicheva

Contemporary Politics 22(2): 144-163, 2016

Over its long history, religion has been a source of unity and peace, and a cause of enmity and brutal conflict. At its best, it has provided the stimulus for life, a motivation for ethical and productive existence, and a divine remedy for human suffering. Religion, at its worst, has fostered tribalism, driven people apart, and served as a catalyst for bigotry, ostracism, and defamation. No other religion has received so much international attention as Islam in the recent decade largely because of its strong association with marking identity differences, motivating conflict, and justifying violence. Although less prominent and widespread, a competing representation of Islam portraying it as a source of unity and peace has appeared in public debates in different parts of the world, especially in the predominantly Muslim societies (Huda, 2010).

How can religion in general, and Islam in particular, play multiple, conflicting, and contradictory political and social roles? This study engages with this question. It contends that there is nothing inherently conflictual or peaceful about either Christianity or Islam. Although, religions' potential for peace has been contemplated less frequently than their potential for violence (Hasenclever, 2012), no religion possesses an intrinsic ability to engender conflict or facilitate cooperation. It is through the various discursive representations that religious premises acquire specific meanings and connotations. As discussed further in this study, the very nature of religion as a system of beliefs, which understandings are circumscribed by historical and sociopolitical context (Ayoob, 2007), lends itself to the process that I term the instrumentalisation of religion. The latter is a deliberately discursive process of packaging the references to religion with certain themes and emotional appeals for the purpose of power legitimation.

The focus of this article is on the instrumentalisation of Islam, which provides a timely and instructive case for the study of instrumentalisation of religion. Central Asia is the geographical domain for this research with the majority of evidence collected in two Central Asian republics - Kazakhstan and Uzbekistan. By different estimates, Muslims constitute 47$75 \%$ of all believers in Kazakhstan, and around $88-96 \%$ of faithful in Uzbekistan. The majority of Central Asian Muslims are Sunnis of the Hanafi School with Shiites constituting only 5-6\% of the Muslim population in these nations (Pew Research Centre, 2012, p. 128). Religion was systematically suppressed during the reign of Communism, but resurfaced as a potent social and political force in the post-Soviet context (Khalid, 2007), not least because of the practical discourses of Western and Central Asian security analysts (Heathershow \& Montgomery, 2014). The different 'guises' under which Islam re-emerged in Central Asian states (see, for example, Hann, 2006; Hann \& Pelkmans, 2009; Peyrouse, 2007), along with the governments' efforts at hijacking the religion engendered a range of discursive portrayals of Islam in the region that are representatives of the 'uses' of religion in other parts of the world.

The study begins with the discussion of the notion of instrumentalisation of Islam and methodology for studying the discursive representations of religion followed by a brief overview of trends and patterns of the Central Asian Islam to provide context for evaluating the governments' discourses. In the next two sections, I present the results of the discourse analysis of the official rhetoric surrounding Islam by the Kazakh and Uzbek administrations. Drawing on 
Mariya Y. Omelicheva

Contemporary Politics 22(2): 144-163, 2016

the empirical findings, I propose a framework linking various discursive representations of Islam to their political uses and discuss the utility of this framework for understanding the impact of religion on politics.

Instrumentalisation of Islam: A Concept and Methodology for Analysis

Religion is perceived through the language of discourse that defines religious ideas, practices and symbols, and re-creates them in public space (Hurd, 2012, p. 36). The primary purpose of religion is to provide salvation, i.e., to liberate the faithful from suffering, evil, finitude, and death. The existence of different religions entails a great variety of beliefs about what constitutes salvation and the means of achieving it (Hasenclever, 2012). The discursive representations of religion serve as the purveyors of meanings that allow the observers to differentiate the promise of salvation in, for example, Islam from that in Catholicism. However, even within the same faith, religious idioms are typically brought to bear on specific objectives that change the actual content and thrust of religious messages employing them (Ayoob, 2005, p. 953). As a result, any religion features multiple, at times competing, interpretations of its orthodoxy and praxis circumscribed by temporal, geographical, and political contexts.

Islam, which lacks a hierarchical organization with a universally recognized leadership, is particularly amenable to multiple interpretations. Islamic tradition does not vest the ultimate authority to mandate how the Quran and its ethical, political, and social injunctions should be interpreted in any one source (Platteau, 2011, p. 245). There are several religious schools of Islamic thought - Ja'fari, Hanafi, Shafi'i, Hanbali, Isma'ili, and Zaydi - established throughout the Muslim world. Despite some common themes and similarities of the religious vocabulary, there is an infinite variety of organizational and ideological differences among them (Ayoob, 2005; 2007). Disagreements persist not only between Islamic theologians, but also self-ascribed Muslims and secular governments on questions of the compatibility of Islam with modernity, human rights, progress, pluralism, and peaceful coexistence with the representatives of other confessions (Ayoob, 2007; Huda, 2010). The relative freedom of interpretation of religious texts permitted within Islam presents various groups and individuals with an opportunity to lay claims to the authenticity of their interpretations of Islamic scriptures and responsibility for defending the faith (Huda, 2010).

This manipulability of Islam that allows stakeholders to adduce their authority to represent Muslims and their faith also presents the possibility for instrumentalisation of religion. The latter refers to the process of mobilization of Islam by the stakeholders out of political expediency or for accomplishing specific political aims (Platteau, 2011). The instrumentalisation of Islam is a deliberately discursive process of packaging the references to Islam with certain themes for varying its connotations and emotional appeals, and highlighting some selected aspects of religion while muting or disparaging others. It inevitably entails reducing the complexity and diversity within the faith to an allegedly authentic and universal, if simplified, account of religion.

Why does religion get instrumentalised? The answer to this question lies in the ubiquity of power in social relations. Power, however, needs to be legitimised (Foucault, 1998, p. 63; 
Mariya Y. Omelicheva

Contemporary Politics 22(2): 144-163, 2016

Rabinow, 1991). The idea of political legitimacy implies a reciprocal relationship between power-holders and their claims to authority in relation to subjects, and subjects who are conscious of the power-holders' right to govern. The principles of legitimacy, therefore, are forms of justifications of the power entitling it to rule (Iugu, 2012). As demonstrated in the following examples, religion has always supplied the ready-made material for representing, asserting, and legitimising old and new forms of authority (Hasenclever, 2012; Mariano, 2011; Zürcher, 2004; Yilmaz, 2011). Despite deep reservations about Islamism, Saddam Hussein, for example, worked extensively with Islamists and Islamic activists outside Iraq for neutralizing Islamist opposition at home and convincing Islamists abroad to support his foreign policy objectives (Helfont, 2014). Political elites in the former Yugoslavia managed to mobilize communities of faith to take up arms to defend or propagate their religion, pursing highly secular goals in the process (Hasenclever, 2012). Over the course of Turkey's history, the Hamidian regime, the Young Turks, the Kemalists and the Neo-Kemalists all employed the available means to argue and defend the case for true Islam in order to strengthen the state and the governing regime (Zürcher, 2004). In all of these examples, the battle for power and political legitimacy that underpin popular support gave rise to the instrumentalisation of religion.

When religion is instrumentalised, the governments are free to use political responses that are consistent with the selected interpretation. When Islam is securitized, i.e., defined as belonging to a domain of security, policy-makers can claim a right to apply 'urgent and exceptional' measures that fall outside the typical religious policies and constitutionallymandated principles of human rights (Buzan \& Wæver, 2003, p. 491). When Islam is depicted as a cultural asset and part of the national heritage, the government can claim responsibility for honouring and nurturing Islam, and protecting it from the 'alien' religious infusions. Different interpretations of Islam can be used to bolster political leaders' Islamic credentials and subvert the challengers to the governing regime. Recent history offers numerous precedents when political leaders, often with a secular background, have utilized Islam as a readily available ideology and instrument of legitimacy to 'deflect criticisms and entrench their power and privileges' (Platteau, 2009, p. 7).

Various Islamic groups and organizations also instrumentalise Islam. Islamism, itself, represents a form of instrumentalisation of religion by individuals and organizations that utilize Islam for accomplishing political aims (Ayoob, 2005; Yilmaz, 2011). What unites a great diversity of Islamist organizations is their quest for a return to the largely mythical period of rule by Prophet Muhammad. This era has been romanticized as a golden time characterised by a superior political structure, cultural codes, laws, and economic arrangements representing human needs. The return to 'pure' Islam of the Muhammad's age is presented as the only viable political response to today's societal challenges and problems. The foundations for this vision of Islam rest on the appropriated and reinvented concepts borrowed from the Islamic tradition (Ayoob, 2005). These interpretations and claims to Islamic knowledge provide Islamists with an ideological weapon that they wield to purge Muslim societies of all innovations and foreign admixtures, which are blamed for Muslim decadence (Platteau, 2011). 
Mariya Y. Omelicheva

Contemporary Politics 22(2): 144-163, 2016

The circumstances under which religion gets instrumentalised are similar to the context and consequences of instumentalisation of ethnicity and nation. Religion, ethnicity, and ideology rise to prominence in times of a political crisis emblematic of the weakening of the ruling authority. In this context, religious and secular groups attempt to re-assert themselves and gain an upper hand in political contestation by resorting to ideological and religious slogans portraying them as legitimate, capable, and authentic, among other things. Zürcher (2004), for example, examined several instances where the Turkish rulers faced acute challenges to their authority and even survival: Sultan Abdulhamid used religion to ward off the threats of nationalism and imperialism; The Young Turks mobilized Ottoman Muslims against the perceived threat of the Christian minorities; and the Turkish nationalists employed religion in their struggle against the occupying forces after the First World War. Moreano (2011) showed the use of religion by political opponents vying for state power in his analysis of the relations between religion and politics in Brazil.

The instrumentalisation of religion is very common in authoritarian regimes suffering from ineffective governance and mired in corruption. In cases like Algeria, Sudan, Pakistan, and others, Islam has been nationalised and used by the state authorities for legitimising their repressive policies and mobilization of the public support (Layachi, 1995; Owen, 1992). The political leadership of authoritarian states may choose to instrumentalise Islam as a way to misplace the sources of social and political concerns or avoid responding to demands of religious and secular opponents (Platteau, 2009, p. 7). All in all, what appear as conflicts between various interpretations of the faith often conceals more down-to-earth struggles between different groups seeking to advance their specific political interests and aspirations.

Various discursive representations of a phenomenon are typically discerned from the actual language of verbal and written communications about the issue. Official representations can be identified from the statements of the governments' representatives converted into texts or stored as texts. These texts include written and printed manuscripts of speeches, transcripts of interviews, and addresses published on the web, all of which are the repositories of utterances and statements (Fairclough, 1992). For the purpose of identifying the discursive representations of Islam in Kazakhstan and Uzbekistan, I identified and analysed all annual addresses and speeches of the Kazakh President Nursultan Nazarbayev and Uzbek President Islam Karimov delivered from 1997 to 2015. ${ }^{1}$ In addition, I used LexisNexis Academic database of newspapers to identify all available news articles containing references to Islam, which were published by non-US newspapers and wires, such as Kazakhstan General Newswire, Central Asian News Services, States News Services, and others, from 1992 through 2015. A total of 8,952 English and Russian-language references to Islam (4,185 from Kazakhstan, and 4,767 from Uzbekistan) were analysed in texts. I used nVivo - qualitative data analysis computer software - for a systematic content analysis of the term 'Islam' and its derivatives in context.

\section{General Trends Characterizing Central Asian Islam}

${ }^{1}$ Those speeches are published on the presidents' official portals. 
Mariya Y. Omelicheva

Contemporary Politics 22(2): 144-163, 2016

Islam in Central Asia is immensely diverse. It manifests itself in a variety of local practices and perspectives that developed from the two concurrent historical processes of indigenization of canonical Islam and Islamicisation of local customs and traditions. Due to this merger of religious canons with traditions and also as a consequence of the Soviet-era ethno-national and religious policies, many Central Asian Muslims exhibit low knowledge of Islamic canonical texts and light observance of Islamic rituals (Khalid, 2007). For instance, in Kazakhstan, only 2$3 \%$ of Muslims pray five times a day or read Quran daily, 10\% attend mosque at least once a week, and 30\% fast during Ramadan. Among the Uzbek Muslims, only 5-9\% report weekly attendance of mosques and daily reading of Quran, 16\% pray five salat, and 50\% fast during Ramadan (Pew Research Center, 2012). According to Privratsky (2001, p. 91), this 'quintessential religious minimalism' characterizing the practice of Islamic faith is reflected in the fact that a simple profession, 'Praise be to God, I am a Muslim', along with the observance of customary practices serve as the substitutes for other obligations. Indeed, the majority of Central Asia Muslims derive their religious identity from a variety of local customary practices - the wearing of protective amulets, visitation of shrines, cults of saints and holy places, and other rituals (Pew Research Center, 2012; Privratsky 2001, p. 78). Muslimness is also derived from being born into a Muslim community (Khalid, 2007, p. 21; Louw 2006, p. 320). The community is ipso facto Muslim, as long as some people (typically, the elderly) fulfil the ritual requirements (Privratsky 2001, pp. 54-57)

The Soviet nationality and religious policies gave rise to the merging of national and religious identification. The Soviet government permitted the private and 'cultural' elements of religious observance and education, which were treated as important markers of the peoples' ethnic heritage, but discouraged mosque visitations and public prayers perceived as 'extreme' religious manifestations incompatible with the ways in which 'Soviet' people defined their Muslimness (McBrien, 2006, p. 344). In this way, the Soviet regime blended the Muslim identity of Kyrgyz, Kazakhs, and Uzbeks with their ethno-national identification. These policies also contributed to the emergence of a phenomenon of 'cultural' or 'ethnic' Muslims (Hilgers, 2009). These faithful are religiously unobservant and secular individuals who nevertheless identify with the Muslim tradition and think of Islam as an important element of their ethno-national identity due to family background, or the social and cultural environment in which they grew up. To this day, for example, sizable populations of the major urban centres in Central Asian countries continue to have little interest in Islam, but still identify with the Muslim cultural tradition. There are also scores of faithful who define their Muslimness through regular prayer and performance of other duties as laid down in the Quran. All in all, religious practices and levels of religious observance are not uniform across Central Asia reflecting a complex multi-ethnic composition of the region, varied socio-economic and cultural conditions, and divisions among the kinship groups (Ro'i \& Wainer, 2009).

Not all Islam in Central Asia is local, and some local religious practices bear a mark of foreign influence. After independence, Central Asia saw an influx of foreign Muslim missionaries arriving from Turkey, Pakistan and the Arab states. Many of these religious groups 
Mariya Y. Omelicheva

Contemporary Politics 22(2): 144-163, 2016

have been highly critical of the local religious practices condemning them as perfidious and blasphemous. These new religious actors have embarked on the 're-Islamicisation' of Central Asian Muslims with the goal of returning them back into the fold of 'genuine' Islam (Biard, 2010). A vast majority of Muslims in Central Asia perceive foreign preachers as manifestly intolerant of their local ways of practicing the faith, whereas the foreign religious ideas are viewed as incompatible with the indigenous Islamic traditions. Still, foreign religious activists, who are typically better educated and certainly better funded, have been able to gain some following in the region (Akiner, 2003). Among the foreign religious groups with the largest presence in the region are the Nurcu and Fetullah Gulen movements. Both groups have engaged with the Central Asian youth, particularly, through the Turkish Lyceums established in all Central Asian republics (with the exception of Uzbekistan where the schools were shut down in 1999) (Balci, 2003). The Nurcu movement has also opened hundreds of small-size enterprises across Central Asia.

Along with more devout, but not necessary extremist forms of Islam, radical Islam has made inroads in the communities of Central Asian Muslims (Fredholm, 2006). The radical qualifier is used to denote those groups that pursue radical changes to the social, political, and moral order, including the secular nature of Central Asian states. Some of the early manifestations of radical Islam appeared in Uzbekistan and Tajikistan. In 1991, Namangan, a small town located in the Uzbek part of the Fergana Valley saw the emergence of Adolat, a radical Salafi Islamist group, initially sponsored by the Saudi funds. It gained control in Namangan through the imposition of Sharia law enforced by the vigilant neighbourhood-watch committees but was banned in 1992. Adolat's members were arrested, while its leaders found refuge in Tajikistan, where they joined the Tajik Islamic Renaissance Party, also banned in Uzbekistan. The participation in the Tajik civil war had further radicalized the movement's leaders who eventually made up a core of the Islamic Movement of Uzbekistan (IMU). The IMU has been implicated in a series of terrorist attacks, raids on Kyrgyzstan, and ties the Al Qaeda and Taliban networks (Naumkin, 2005). The IMU was severely weakened in combat with the US and allies' force in Afghanistan, and its remnants jointed with other Islamists in Central Asia, Afghanistan, and Pakistan.

Hizb ut-Tahrir is another radical Islamic group with a significant and growing presence in Central Asia. The group pursues a pan-Islamic goal of establishing a region-wide Caliphate ruled by sharia, but contrary to other jihadist movements, it eschews violence as a means toward accomplishing this goal (Karagiannis, 2005). The Central Asian authorities have also made announcement about the presence of other radical groups in their states, such as Akramiya in Uzbekistan, and the Tablighi Jamaat in Kyrgyzstan and Kazakhstan (Laumulin, 2011).

\section{Discursive Representations of Islam in Kazakhstan}

Presiding over the country where almost 70 per cent of population self-identify as Muslims, according to a national census (The Agency for Statistics of the Republic of Kazakhstan, 2010), President Nazarbayev has skirted frequent references to Islam. The analysis of word frequencies in Nazarbayev's speeches delivered since 1997 shows that the themes of 'international' $(1,206$ 
Mariya Y. Omelicheva

Contemporary Politics 22(2): 144-163, 2016

references), 'development' (1,175 references), 'economy' (1,160 references), and 'reform' (536 references) dominate the presidential discourse. Islam and its derivatives were mentioned 163 times, but almost never in connection with Kazakhstan being an Islamic or Muslim country. In recent years, in particular, the Kazakh President began placing more emphasis on a secular nature of Kazakhstan. In his 2006 Presidential address, for example, Nazarbayev affirmed that his government would 'respect and nurture the best traditions of Islam and of other world and traditional religions, while [...] building a modern secular state' [emphasis added] (Nazarbayev, 2006). In his 2011 address to the Organization of Islamic Cooperation (OIC), the President reiterated that Kazakhstan was 'a secular state with a Muslim majority population' (Nazarbayev, 2011). In his 2014 address to the people, Nazarbayev characterized Kazakhstan's society as a 'secular society with high spirituality' (Nazarbayev, 2014).

When mentioned, Islam and the associated terms have been used in one of the following contexts. First, throughout the entire period of the study, Islam has been portrayed as a source of national unity and an instrument of consolidation of the diverse ethnic groups under the umbrella of one state. In his congratulatory speeches on Islamic holidays, Nazarbayev has habitually stressed how these commemorations have strengthened the solidarity of the Kazakh people, and that Islam's major contribution to Kazakhs has been in 'advocating peace, mercy and respect for other religions' (Kazakhstan News Agency, 2005). This unifying and mollifying role of religion has been discursively ascribed to a particular kind of Islam, namely, the 'forefathers' Islam', that exhibits 'a harmonious accord between the [Islamic] great teachings and own traditions and customs' of Kazakhs (Kazakhstanskaya Pravda, 2011). According to the President, this 'true', 'real', and 'authentic' Islam does not preach to 'take arms, fight, kill others, violate the law and go against the state' but promotes tolerance and contributes to 'spiritual renewal' of the Kazakh people (Khabar TV, 2000). It also encourages support for the Motherland and furthers allegiance to state. As President Nazarbayev once explained, 'I believe that Islam purifies a human being's spiritual world by teaching [...] to help each other in difficult situations, to unite around a state, to love one's Motherland' [emphasis added] (Khabar TV, 2000). Thus, the 'real' Muslim faith has been portrayed as part of the spiritual, traditional, and moral fabric of the Kazakh society separated from state politics.

It is this 'cultural' and a-political Islam that has been discursively embraced and supported by the government. The regular congratulations of the President to the Kazakh and world Muslims, and proclamations of the establishment of new centres and institutions of Islamic learning have been used to depict the Kazakh government's respect for the best traditions of Islam. The official discourse about Islam has also assured that the government's support for religion does not violate the principles of secular and modern state. The latter image has been discursively reinforced through frequent allusions to the people's right to practice any faith and guarantees of equal treatment of all religions.

The President's attempts at reconciling modernity and Islam and creating an image of a progressive state that is attuned to its national traditions have become a conspicuous theme since 2007. It was around this time that Kazakhstan began asserting a new leadership position in the 
Mariya Y. Omelicheva

Contemporary Politics 22(2): 144-163, 2016

dialogue between Muslim countries and the West through references to its role in organizing congresses of representatives of the world religions, participation of the Kazakh representatives in economic forums with other Muslim states, and Kazakhstan's chairmanship of the OIC. President Nazarbayev has stressed the need for the Muslim community to modernize, and volunteered Kazakhstan's experiences in creating a legislative environment that allows the introduction of Islamic banking in a capitalist market economy, as a validation of Kazakhstan's 'natural' role in spearheading the process of modernization (AKIpress, 2014).

The rhetoric of President Nazarbayev and members of his cabinet has clearly differentiated between the peaceful and non-threatening Islam of the Kazakh people from dangerous Islamic varieties that are inimical to their 'authentic' Islamic tradition. Two rhetorical strategies have dominated these efforts. First, the Kazakh government has tried to discredit the threatening 'fundamentalist' Islam as un-Islamic and 'not real Islam of the Koran.' President Nazarbayev has been quoted asserting how 'extremist Islam is political manipulation,' and 'fanaticism has [...] been alien to the tradition of Islam in Kazakhstan' (Dan, 2003). Kazakhstan's religious authorities have generally echoed the President's sentiments. In recent years, the chairman of the Religious Affairs Committee of Kazakhstan's Ministry of Culture criticized the media for using the 'Islamist' label with Islamic State. Instead, he referred to the group as a 'gang' with no relation to Islam (Kazakhstan News Agency, 2015).

Not only did Nazarbayev and representatives of the Kazakh Muftiate attempt to root out 'false stereotypes' about Islam but they also made every effort to create an image of Kazakhstan as different from other Muslim states, especially the Arab nations. The representatives of the Kazakh government have repeatedly stated that Islamic fundamentalism was less likely in their republics than in other states, because Kazakh Muslims categorically oppose violence, mutiny, and suicide. It has been also implied that the intelligent policies of the Nazarbayev's administration contributed to the peaceful coexistence of Kazakhstan's traditional religions and precluded the rise of radicalism in Kazakhstan. President Nazarbayev once explained, 'We have developed a unique formula of national unity regardless of religious and ethnic background of our citizens' (Kazakhstan News Agency, 2012).

The topic of Islamic danger is also prominent in the official discourse, especially in the statements of law-enforcement and security officials. 'Foreign terrorist groups are active in Kazakhstan;' 'Wahhabis pose the greatest threat to the country;' South Kazakhstan is 'the most suitable' place for 'various extremist elements.' These and similar statements are emblematic of the rhetoric used by the Kazakh National Security Committee and its spokespersons. References to certain threatening manifestations of Islam tend to increase following the news of major terrorist attacks in the neighbouring states and overseas and, since recently, the Islamic State's recruiting efforts in Central Asia. The dangerous varieties of Islam described with blanket terms of 'extremist' or 'Wahhabis' have always been discursively linked to sources outside of Kazakhstan. Typically Afghanistan and Pakistan, but also Kazakhstan's tumultuous neighbours have been mentioned as the cradle of Islamist danger. The rhetoric of Islamist threat has been accompanied by the statements displaying Kazakhstan's commitment to rooting out this threat, 
Mariya Y. Omelicheva

Contemporary Politics 22(2): 144-163, 2016

stressing the importance of regional counterterrorism cooperation, and affirming its role as an active member of the international coalition against terrorism and religious extremism.

\section{Discursive Representations of Islam in Uzbekistan}

What sets the official discourse of Islam in Uzbekistan apart from the rhetoric in the neighbouring Kazakhstan is its expressly alarmist tone. Between 1997 and 2007, the prevailing representations of Islam in Uzbekistan had been discursively connected to the themes of violence, threat, and immanent danger. In the late 1990s, the speeches of the Uzbek President Islam Karimov brimmed with admonitions about the upsurge of Islamist forces. 'This danger is very grave and increasing day by day, primarily in terms of ideological expansion', asserted the President (Nezavisimaia Gazeta, 2004). Karimov has also been an outspoken critic of the conciliatory approaches to Islamism and defended the exigency of resolute measures and tighter religious regulations (Omelicheva, 2011).

In 1999-2000, following the February 1999 explosions in Tashkent and the IMU incursions in Kyrgyzstan, Uzbekistan's informational medium became inundated with reports about 'terrorist attacks' and 'militant' and 'guerrilla' operations of the Islamist forces. The year of 2004 saw more violent attacks in Uzbekistan leading to proliferation of reports about terrorist violence and the counterterrorism operations that ensured. The infamous Andijan incident that took place in May 2005 when the Uzbek government troops fired at the protesters killing hundreds of demonstrators became the top theme in 2005 and the subsequent years. The official discourse presented the unrest as the IMU plot to subvert the legitimate and secular regime in Tashkent and labelled the protesters as the Hizb ut-Tahrir members. In addition to repeated warnings about the growing threat of terrorism and religious extremism, the official rhetoric of the Uzbek government contained appeals to the international community to unite in a fight against these 'evil forces'. Beginning with 2001, the theme of counterterrorist cooperation with Russia, China, and other Central Asian states, and, later, with the US as part of the global antiterrorist coalition became more prominent in references to Islam and discussions of religion.

To this day, the references to Islam in Uzbekistan are frequently placed in the context of discussions of the persistent threat of religious extremism, terrorist attacks in the bordering states, on-going insurgency in Afghanistan and Pakistan, and risks associated with the withdrawal of coalitional forces from Afghanistan. Similarly to the discursive presentations of Islam in Kazakhstan, the government of Uzbekistan has portrayed dangerous manifestations of Islamic beliefs as un-Islamic and a-religious. The chief Mufti of Uzbekistan condemned Islamic groups espousing these dangerous views for poor understanding of Islam, and derided their literature as 'absolute nonsense, slander, and obvious distortion of Koranic verses'. The government has repeatedly charged the adherents of 'dangerous Islam' with a range of 'political and other aggressive goals' and denounced them for subverting democracy, hindering reforms, and threatening stability in Uzbekistan (Karimov, 1998; 2000). In the 1990s, the emergence of these dangerous Islamic varieties was blamed on colonialism and communism, which a-spiritual, 'fanatical', and 'anti-national' character 'contributed greatly to the formation of the prerequisites for religious fundamentalism' in the post-Soviet countries (Karimov, 1998). In the 2000s, the 
Mariya Y. Omelicheva

Contemporary Politics 22(2): 144-163, 2016

Uzbek government has discursively shifted the source of terrorist danger to weak and unstable states in Uzbekistan's proximity. Similarly to the government of Kazakhstan, the Uzbek authorities always denied that their country provided a fertile ground for the emergence of radical expressions of Islam. The recent influx of Uzbek militants fighting alongside the Islamic State has been blamed on the indoctrination and recruitment of the migrant workers from Uzbekistan in Russia (Radio Free Europe, 2015).

The themes of traditional Islam and the government's support for religion have also cropped up in the rhetoric of the Uzbek officials. Traditional Islam has been described through the invocation of admirable personal qualities characterizing Uzbeks, such as tolerance, benevolence, and hospitality. By refashioning Islamic tradition into the composite of traditional values of Uzbeks, rather than religious practices and knowledge associated with Islamic scriptures, the official discourse has presented traditional Islam as both a-political and areligious. The presentations of Islam as part of culture and moral fabric of Uzbeks have been reinforced by frequent references to Uzbek forbearers - scientists, philosophers, poets, and heroes - consecrated as 'saints', and celebrated in Uzbekistan's modern national arts and culture. As President Karimov once explained, "we can never imagine our religion without those great persons, and the names of those great persons - without the religion of Islam' (Uzbekistan National News Agency, 2007). To learn about the great national history and culture of Uzbekistan, President Karimov called on the Uzbek children to go to schools, not to mosques, a position shared by the Uzbek Muftiate.

It is this cultural and spiritual Islam that has received the Uzbek government's recognition and support. President Karimov once explained, 'from the first days of our independence a major task, at state policy level, has been to revive the invaluable spiritual and cultural legacy that has been moulded by our ancestors over many centuries' (Karimov, 1998). The President's messianic role in safeguarding the national traditions and ensuring the continuation of cultural Islam is subtly implied in this and similar references. When the Uzbek president or government officials speak of the state's courtship of Islam citing the growth of mosques, creation of educational centres, and observation of religious holidays, these acclamations are followed by important caveats. It has been repeatedly stated that the government will support the national Islamic tradition, but will resist all efforts at 'importing' Islam from outside and attempts at politicising the religion. In 1998, for example, the Uzbek government established fines and jail terms for wearing religious clothing in public, and in 2012 it prohibited the sale of hijabs and face veils explaining the practice of wearing religious clothing as inconsistent with the Uzbek culture.

The compatibility of cultural Islam with secular, modern, and democratic statehood that is being built in Uzbekistan is another theme that can be spotlighted in Uzbekistan's official rhetoric in recent years. It has been asserted, for example, that the 'positive values' of the modern civilization (especially those related to the rule of law and human rights) do not go against the 'grain of the [Uzbek] nation either historically or ethno-culturally' (Karimov, 1998). The compatibility of Islam with modernity has been affirmed through frequent references to the 
Mariya Y. Omelicheva

Contemporary Politics 22(2): 144-163, 2016

Uzbek government's accomplishments in the economic and political realms, while the compatibility of religion with 'democracy' and secularism in Uzbekistan has been attested by highlighting differences between Uzbekistan and other Arab states and declaring the government's adherence to the freedom of religion. Despite the portrayals of Uzbekistan as different from other Muslim nations, the Uzbek government has nonetheless levelled claims to the outstanding contribution of the Uzbek religion to the development of Islamic civilization. The Uzbek president, government and media have presented their country as the cradle of world civilization that preserved some of the 'jewels' of Islamic heritage.

\section{A Framework of Political Uses of Religion}

The analysis of the official discourses of Islam in Kazakhstan and Uzbekistan revealed several dominant themes (see Figure 1). In both states, the discourse of dangerous varieties of Islam prevailed relative to other topics, especially between 1992 and 2007, as shown by the frequency of references to Islam in the context of discussion of terrorist attacks, Islamist incursions, and threats associated with religious extremism in Central Asia (420 references in Kazakhstan and 448 in Uzbekistan). Also prominent is the theme describing these states' participation in the national, regional, and global efforts aimed at combatting terrorism (166 and 255 references to individual and joint counterterrorism measures in Kazakhstan and Uzbekistan respectively). The topic of traditional Islam, which encompasses the discussion of Islam as part and parcel of the Kazakh and Uzbek culture and tradition and illuminates its positive characteristics, such as Islam's inherent propensity for unity and peace, appeared in 108 references in Kazakhstan and 94 in Uzbekistan. Traditional Islam was discursively separated from foreign and extremist expressions of religion, and this juxtaposition was explicitly mentioned in 38 references in Kazakhstan and 13 references in Uzbekistan. Seventy-four references to Islam in Kazakhstan and 48 in Uzbekistan were dedicated to various forms of state support to traditional and 'official' Islam. In both states, the theme of collaboration with other Muslim states has become prominent in recent years (210 and 102 references in Kazakhstan and Uzbekistan respectively), and in Kazakhstan, official discourse has promoted the republic's leadership role in the Muslim world, including in fostering the inter-confessional dialogue (60 references).

\section{[Figure 1 about here]}

These dominant themes are indicative of several discursive portrayals of Islam as well as their functional uses. In the remainder of the article, I introduce a framework of instrumentalisation of Islam developed inductively from the evidence collected in the Central Asian republics. I propose to classify the discursive representations of Islam into four generic categories of 'traditional,' 'official,' 'radical/foreign,' and 'moderate/modern,' which are neither exhaustive nor mutually exclusive (for example, the category of 'official' Islam overlaps with both 'traditional' and 'moderate/modern' categories) (see Figure 2). The goal of this classification is to systematize the discursive images of Islam and to show how they serve specific political goals.

\section{[Figure 2 about here]}

The construction of the image of 'traditional' Islam has clearly served the Kazakh and 
Mariya Y. Omelicheva

Contemporary Politics 22(2): 144-163, 2016

Uzbek governments' nation-building goals. The rewriting of Uzbekistan's national history purged of the Russian/Soviet vestiges has become a key part of its nation-building project. President Karimov has sought to present Uzbeks as an ancient civilization on par with China, India, and Greece, and used Islam as a core element within a uniquely Uzbek cultural, historical, and religious heritage (Peyrouse, 2007, p. 245). By rehabilitating Islamic intellectuals and traditions, the Uzbek government has framed 'traditional' Islam as an important marker for Uzbek national identity that shapes the 'nation's social organization and gives it a moral and ethical framework' (Hann, 2006, p. 83). Keenly aware of the place of Islam in Uzbeks' selfidentification, President Karimov has managed to mobilized Islamic faith for fostering nationalism, and also presented himself as its symbol. Karimov, for example, has successfully drawn discursive linkages between his personal beliefs and those of representatives of the Uzbek Islamic heritage, in this way not only defending his Islamic reputation, but also giving credence to his policies.

The Kazakh government, too, has appropriated Islam as a national marker and attempted to foster a sense of national unity among the Kazakhs, Uzbeks, Uighurs, and other Muslim minorities through its appeals to the common religion. ${ }^{2}$ Instead of searching for and articulating the common cultural bases of a national identity of the multi-ethnic and poly-confessional states and forging this unity through real practical measures, the Central Asian governments asserted harmony and unity among ethnic groups cementing it by appeals to a common Islamic tradition without making its content explicit. Furthermore, the governments have claimed the right to defend this constructed unity through state support for the so-called 'traditional' religion, while denying recognition and even prosecuting those manifestations of Islam that are deemed incompatible with the vaguely defined 'traditional' or 'official' religion.

The discursive presentation of Islam as 'traditional' and 'official' has provided the governments with the necessary context for institutionalising state control and formalising governments' interference in religious affairs. Central Asian governments' administrative supervision of religion has been enforced through the mandatory registration of religious associations, determination of qualifications for clergy, censorship of religious literature and information, and setting the parameters of theological discourse. Unregistered religious and missionary activity and private religious instruction are either prohibited or criminalized across Central Asia. All states, but Tajikistan, banned the creation of religious political parties and movements. These and other practices violate many internationally and constitutionally guaranteed rights connected with religious freedom. By creating a discursive image of 'official'

${ }^{2}$ In the meetings with the Russian government or representatives of the Orthodox Church in Kazakhstan, the Kazakh president and representatives of his administration would stress 'the historical role of Islam, the Hanafi doctrine' but also the Orthodox Christianity in cultural development and spiritual life of the people of Kazakhstan (Kazakhstan News Agency, 2011). 
Mariya Y. Omelicheva

Contemporary Politics 22(2): 144-163, 2016

Islam, the governments have brought religion into the realm of 'public' affairs making it subject to state regulation. These efforts have been premised on the belief that unregulated Islam is a threat to the governing regimes. By intrumentalising Islam, the governments have been able to set limits to a range of practices associated with 'official' religion, while excluding all other possibilities for action in relation to Islam.

In the official discourses of Kazakhstan and Uzbekistan, the threatening varieties of Islam have been discursively linked to the 'radical' and 'foreign' manifestations of religion. By securitizing 'radical Islam', the Central Asian governments have justified the use of 'urgent and exceptional measures that fall outside of the typical political processes' to deal with the discursively created threat (Buzan and Weaver, 2003, p. 491). ${ }^{3}$ The inescapable ambiguity of the terms associated with 'radical' and 'foreign' Islam employed in the discourse of Islamic danger allowed the governments to associate all political opposition with increasing Islamic radicalization (Heathershaw \& Montgomery, 2014) and stamp out any activity perceived as threatening to the governing regimes.

The rhetorical hype about the governments' efforts at protecting their countries and peoples from the dangers of radical Islam has also served to boost the Central Asian leaders' reputation. In Uzbekistan, President Karimov has portrayed himself as the last bastion against Islamist insurgency. The leadership of Kazakhstan and Uzbekistan has argued persuasively that their governments have effectively supplied security to their states and Central Asian region. These security agendas were discursively connected to the demands of population. In other words, the counterterrorism policies of the Kazakh and Uzbek governments have been framed as consistent with the citizens' needs (Omelicheva, 2013).

Instrumentalisation of Islam has also been used to mask the underlying causes of enduring socio-economic and political problems: poverty, unemployment, lack of opportunities, disregard for human rights, and authoritarianism. All Central Asian governments have tried to externalize the structural and institutional failures produced by deficiencies in their rule onto the existential threat of radical Islam. The latter has been blamed for redirecting states' efforts away from public and social programs and obstructing the governments in carrying out political and social reforms (Kaya, 2007, p. 7).

Finally, the discourse of 'moderate' Islam (which has also been admitted as 'official') has benefitted Central Asian governments in, yet, another way. It has been utilized in the process of

${ }^{3}$ Numerous instances of unfair trails, arbitrary detentions, and executions of Islamists have been carried out in the name of combating terrorism. President Karimov, for example, was quoted saying "it is better to have hundreds of arrested than thousands killed," in an attempt to justify his human rights violations committed under the pretext of fighting terrorism (Matveeva, 2009, p. 1109). 
Mariya Y. Omelicheva

Contemporary Politics 22(2): 144-163, 2016

creating an international image of Central Asian republics as modern secular states and active participants of the global war on terror. For Western states and institutions, this image has been contingent on the republics' commitment to democratic reforms and respect for human rights and religious freedoms. Furthermore, the Western understanding of modernity relegates religion to the realm of personal preferences and cultural attributes, thus denying the faith a prominent place in state politics. Kazakhstan's authorities resorted to the popular framing of Islam in terms of the binary opposition between its 'moderate' and 'radical' varieties representing the former as a constitutive element of national identity and culture and, therefore, compatible with the modern secular state. The strict religious policies and religious persecution have been portrayed as the government's contribution to the worldwide efforts to halt the proliferation of radical Islam. Kazakhstan has even championed the idea of 'liberal versions of political Islam, compatible with democracy and the West' for enhancing its image as a bridge between the West and the East (Siddiqui, 1992).

All of the discussed uses of Islam serve one overarching purpose of power legitimization. The instrumentalisation of religion has assisted the Central Asian governments in safeguarding their power grip and denying authority to religious and secular opposition. Central Asian rulers have bolstered their nationalist credentials by declaring support for the discursively created 'traditional', 'official', and 'moderate' varieties of religion. In doing so, they have diverted public attention from the lingering deficiencies of the rule by their corrupt, secretive, and authoritarian administrations. Furthermore, conscious of the strategic importance of their states, power elites have exploited the fear of radical Islam, as well as the context of the global war on terror, to justify and intensify their suppression of dissent, without much concern about international condemnation.

For the instrumentalisation of Islam to serve the purpose of political legitimation, it has to take place in the appropriate context that makes religious representations both plausible and compelling (Hasenclever, 2012). In Central Asia, Islamic faith has played an important role in everyday social life of the Muslim populations, who tend to identify with the localized forms of Islam. During the Soviet time, these local Islamic practices and beliefs were relegated to the 'cultural' and 'popular' realms contrasted with the 'parallel' or 'underground' Islam represented, for the most part, by the clandestine Islamic movements and Sufi orders (Louw, 2007, p. 5; Rasanayagam, 2010, p. 90). Soviet observers defined 'parallel' Islam negatively as 'Islamic institutions and clergy existing and operating outside the sanctioned sphere of the governmentcontrolled official Soviet Muslim establishment' (Louw, 2007, p. 4). Thus, already during the Soviet period many Central Asian Muslims and non-Muslims alike became attuned to thinking about Islam in terms of simple dichotomies of 'traditional' and 'official', on one hand, and 'parallel' and 'underground', on the other hand. The contemporary discourses of 'traditional' and 'radical' Islam feed off these deeply ingrained dualisms and objectified beliefs in the 'popular' and 'parallel' Islam, only now the juxtaposition of 'cultural'/'popular' and 'parallel'/'clandestine' is replaced with the opposition between 'traditional' Islam rooted in the local history and 'radical' Islam that is alien to the Central Asian people. 
Mariya Y. Omelicheva

Contemporary Politics 22(2): 144-163, 2016

The regional and international environment has also been conducive to the instrumentalisation of Islam. Even before the 9/11 attacks, Russia, Uzbekistan, and China cultivated the discourse of Islamist danger in the region in pursuit of their own geopolitical aims (Omelicheva, 2011). Following the inception of the global war on terror, the terminology used by mass media concerning Islam became fused with the dangers of terrorism and Islamic radicalization (Creutz-Kämppi, 2008). This prevailing understanding of Islam as a source of violence, regardless of the context, was soon contested by portrayals of Islam as an inherently peaceful faith (Gallagher \& Patterson, 2009, pp. 6-11). Subsequently, the simple binary representations of Islam as tolerant/spiritual and intolerant/fundamentalist have been popularized and reified.

The described discursive representations of Islam have also been informed by the existing understandings of the nature of the relationship between modern states and religion. Secularism has long become one of the important organizing principles of modern politics and contemporary thinking about international relations. The so-called 'Laicist' trajectory envisions secularism as an imperative for modernization, while religion is perceived as an adversary to democracy and an impediment to creation of modern states (Ayobb, 2008; Platteau, 2011; Zürcher, 2004). Islam in this conception is treated as a daunting but surmountable obstacle to democracy and modernization (Hurd 2008, p. 47). Framed this way, Islam is juxtaposed to the secular and in need of accommodation. To argue for the compatibility of some expressions of Islam to democracy, the Laicist thinking has encouraged the construction of 'moderate' and 'modern' varieties of Islam, while the widespread practices of relegating religions identity to the status of cultural attribute in some Western states have reinforced the discourses of 'cultural' and 'popular' Islamic traditions.

\section{Concluding Remarks}

This study conceptualized the phenomenon of instrumentalisation of religion and offered an empirical analysis of instrumentalisation of Islam in Kazakhstan and Uzbekistan. It highlighted various representations of Islam in the official discourses of these Central Asian republics and showed how these 'images' have served the purpose of legitimation of the governing regimes. The conceptual framework of the instrumentalisation of Islam developed on the basis of information collected in Central Asian countries is compatible with empirical evidence from the earlier studies demonstrating how secular and religious rulers in need of popular and international support as well as their secular and religious opponents utilize religion as a legitimising instrument (Platteau, 2009, p. 5; Helfont, 2014; Moreano, 2011; Zürcher, 2004).

The arguments advanced in this study aim to make several contributions to theoretical developments in political science and international relations. Sociologists have long recognized the 'double' function of religion in the legitimation of power and in protest and opposition (Billings \& Scott, 1994), and these insights have recently transpired in the studies of religion and modern politics in political science and its various subfields. If the scholarly and political communities agree by now that religion matters, there is still significant progress to be made in 
Mariya Y. Omelicheva

Contemporary Politics 22(2): 144-163, 2016

our understanding of how and why it matters and under what conditions it is likely to bring division or unity, and violence or peace.

What this study demonstrated is that religion and religious discourses that constitute it are forms of political authority in their own right. The discursive representations of religion are an example of 'soft' power exercised through the creation, dissemination, and reproduction of specific meanings with embedded evaluative and normative content. These discursive images not only render intelligibility to a phenomenon of religion but they also serve as the instruments of social control and regulation. The instrumentalisation of Islam, as a discursive process of legitimization of the stakeholders' political interests and decisions, represents a kind of 'worldmaking power' in a sense that it involves the ability to construct and impose the 'legitimate vision of the social world and of it divisions' (Bourdieu, 1987, p. 13). The various representations of Islam are interwoven with forms and patterns of political authority, each with their own political interests and convictions. The contestations of the official political settlements involving state and religion that are commonly manifested in the religious resurgence and state efforts at controlling the faith are not merely the conflicts between various religious or secular and religious groups, but more down-to-earth struggles for access to political power and the economic privileges that go with it.

The instrumentalisation of religion entails important consequences for national and international politics and ways in which we study them. Discussing a complex phenomenon of religion by falling back on the simple dichotomies, such as 'traditional' and 'radical' leads to oversimplification, objectification, and trivialisation of its nature. It divorces religion from the tempo-spatial contexts that gives the faith its meaning and purpose, and conceals the fact that religious representations are theological and socio-cultural constructs (Ayoob, 2005, p. 953). In Central Asia, for example, no practice, ritual, or a set of beliefs identified as Muslim is distinctly religious or cultural, but is almost always an intricate blending of the two (Rasanayagam, 2011, p. 242; See also Asad, 1986). There is a number of avowedly apolitical Muslim organizations in Central Asia - Tablighi Jamaat in Kyrgyzstan and the Ismailis in Tajikistan, to name but a few. These groups are neither 'traditional' nor 'foreign,' but definitely 'unofficial.' They, therefore, are routinely regarded with extreme suspicion as stepping stone to radicalism by the Central Asian regimes (Heathershow \& Montgomery, 2014).

The instrumentalisation of religion perpetuates damaging religious myths. When applied to Islam, it reinforces beliefs that Islamic religion is a monolithic phenomenon, which is also inherently anti-secular, violent and anti-democratic. Islamists are framed as 'single-minded fanatics' obsessed with the installation of sharia and incapable of building coalitions or making political compromises (Ayobb, 2005). In the context of Central Asia, these widespread convictions perpetuate beliefs about the receptiveness of Central Asian Muslims to foreign indoctrination and about the growing threat of religion radicalism. In reality however, the region remains an infertile ground for international ideological and political linkages between Central Asian and other Muslims, and the extent of religious radicalization has been exaggerated by both the Central Asian governments and Islamists themselves (Heathershow \& Montgomery, 2014). 
Mariya Y. Omelicheva

Contemporary Politics 22(2): 144-163, 2016

Viewing all Islam as anti-secular, political, and dangerous distract from the wider reality of a post-Soviet Muslim population that adheres to secular principles and the privatization of religious faith.

Preventing the instrumentalisation of religion requires a thorough consideration of how avowedly secular and theocratic governments and their opponents seek to utilise religious traditions and religious discourse. As discussed above, a major factor in this process is the extreme reduction of complexity of religious traditions to a few catchy idioms. A solid religious education and public religious debates on these issues could sharpen believers' religious awareness of the necessary complexity of their own traditions, thus serving as an antipode to instrumenalization of religion (Hasenclever, 2012). Seeking to control religion through restrictive policies and discourse, the governments inadvertently, contribute to the emergence of social forces ready to embrace alternative Islamic expressions, which may be destined to transform themselves into radical forms. This is because not even the most efficient authoritarian state can fully suppress opposition expressed through the religious idiom (Platteau, 2009). When both the state and opposition group invoke Islam as the main justification for their policies and actions, they lock themselves in a prolonged and futile religious bidding war (Platteau, 2011). When the governments become captives of their own understandings of the magnitude and nature of Islamic threat, the discourse of radical Islam becomes a dangerous discourse for politics and societies of these nations. 
Mariya Y. Omelicheva

Contemporary Politics 22(2): 144-163, 2016

\section{References}

The Agency for Statistics of the Republic of Kazakhstan (2010) Public Census 2009, available at: http://www.stat.kz/p perepis/Pages/n1 12 11 10.aspx, accessed 1 June 2012.

Akiner, S. (2003) 'The Politicisation of Islam in Postsoviet Central Asia', Religion, State \& Society 31, 2, pp. 97-123.

AKIpress. (2014) Speech of President of Kazakhstan at World Islamic Economic Forum in Dubai, 29 October. Retrieved from LexisNexis Academic.

Asad, T. (1986) The Idea of an Anthropology of Islam (Washington, Georgetown University Press).

Ayoob, M. (2005) 'The Future of Political Islam: The Importance of External Variables', International Affairs, 81, 5, pp. 951-961.

Ayoob, M. (2007) The Many Faces of Political Islam: Religion and Politics in the Muslim World (University of Michigan Press).

Balci, B. (2003) 'Fethullah Güllen's Missionary Schools in Central Asia and Their Role in the Spreading of Turkism and Isla', Religion, State \& Society 31, 2, pp. 151-77.

Barnett, M. \& Duvall, R. (2005) 'Power in International Politics', International Organization 59, 1, pp. 39-75.

Biard, A. (2010) "The Religious Factor in the Reification of "Neo-Ethnic" Identities in Kyrgyzstan', Nationalities Papers 38, 3, 323-35.

Billings, D. \& Scott, S. (1994) 'Religion and Political Legitimation', Annual Review of Sociology, 20, pp. 173-202.

Bourdieu, P. (1987) 'What Makes a Social Class? On the Theoretical and Practical Existence of Groups', Berkley Journal of Sociology 32, pp. 1-18.

Buzan, B. \& Wæver, O. (2003) Regions and Powers: The Structure of International Security (Cambridge, Cambridge University Press).

Creutz-Kämppi, K. (2008) 'The Othering of Islam in a European Context', Nordicom Review, 29,2 , pp. 295-308.

Dan, Uri. 2003. 'Islam Under Snow', Jerusalem Post, 20 February. Retrieved from LexisNexis Academic.

Fairclough, N. (1992) Discourse and Social Change (Cambridge, Polity Press).

Foucault, M. (1998) The History of Sexuality: The Will to Knowledge (London, Penguin).

Fredholm, M. (2006) 'Islamic Extremism as a Political Force, A Comparative Study of Central Asian Islamic Extremist Movements', Asian Cultures and Modernity, 12, pp. 19-30.

Gallagher, J. \& Patterson, E.D. (2009) 'Approaching the War of Ideas' in Patterson E.D. \& Galligher, J. (eds.) (2009).

Hasenclever, A. (2012) 'War on Earth and Peace from Heaven: Preventing Religions from Instrumentalisation', in Czada, R., Held, T. \& Weigardt, M., Religions and World Peace: Religious Capacities for Conflict Resolution and Peacebuilding (Baden-Baden, Nomos), pp. 184-195. 
Mariya Y. Omelicheva

Contemporary Politics 22(2): 144-163, 2016

Hann, C.M. (2006) The Postsocialist Religious Question: Faith and Power in Central Asia and East-Central Europe (LIT Verlag).

Hann, C. \& Pelkmans, M. (2009) 'Realigning Religion and Power in Central Asia: Islam, Nation-State and (Post)Socialism', Europe-Asia Studies 61, 9, pp. 1517-41.

Heathershow, J. and Montgomery, D.W. (2014). 'The Myth of Post-Soviet Muslim Radicalization in the Central Asian Republics', The Royal Institute of International Affairs: Chatham House, 29 December, available at:

http://www.chathamhouse.org/sites/files/chathamhouse/field/field_document/20141111P ostSovietRadicalizationHeathershawMontgomery.pdf

Helfont, S. (2014) 'Saddam and the Islamists: The Ba'thist Regime's Instrumentalization of Religion in Foreign Affairs', The Middle East Journal, 68, 3, pp. 352-366.

Hilgers, I. (2009) Why Do Uzbeks Have to Be Muslims?: Exploring Religiosity in the Ferghana Valley (LIT Verlag, Halle Studies in the Anthropology of Eurasia).

Huda, Q. (Ed.) (2010). Huda, Crescent and Dove: Peace and Conflict Resolution in Islam (Washington, D.C., The United States Institute of Peace).

Hurd, E. S. (2012) 'The Politics of Secularism', in Shah, T.S., Stepan, A. \& and Toft, M.D. (eds) (2012).

Iuga, N. (2012) 'Issues of Legitimizing Political Power in the First Half of the Twentieth Century: Max Weber and Karl Jaspers', Public Administration \& Social Policies Review, 2, 9, p.5.

Karagiannis, E. (2005) 'Political Islam and Social Movement Theory: The Case of Hizb utTahrir in Kyrgyzstan', Religion, State and Society, 33, 2, pp. 137-150.

Karimov, I. (1998) Uzbekistan on the Threshold of the Twenty-First Century: Challenges to Stability and Progress (New York, St. Martin's).

Karimov, I. (2000) Address by H.E. Mr Karimov at the First Session of Oliy Majlis of the Republic of Uzbekistan (Second Convocation). Retrieved from LexixNexis Academic.

Kazakhstan News Agency (2005) 'Kazakh Leader Hails Muslims for Preserving Stability, Accord', 4 June (in Russian). Retrieved from LexixNexis Academic.

Kazakhstan News Agency (2011) 'Religious Influence in Kazakhstan Rising - Government Official', 22 September. Retrieved from LexixNexis Academic.

Kazakhstan News Agency (2012) 'Nazarbayev Calls on the Global Community to Be More Sensitive to Muslim Societies', 30 May. Retrieved from LexisNexis Academic.

Kazakhstan News Agency (2015) 'Kazakh Official: Don't Call IS Militant “Islamists”, 16 March. Retrieved from LexisNexis Academic.

Kazakhstanskaya Pravda (2011) 'Kazakhstani President Congratulates Muslims on Eid al-Adha holiday', 7 November. Retrieved from LexisNexis Academic.

Kaya, A. (2012) Islam, Migration and Integration: The Age of Securitization (New York, Palgrave Macmillan).

Khabar TV (2000) 'President Nazarbayev Says He Supports “Real and Pure” Islam', 16 March. Retrieved from LexisNexis Academic. 
Mariya Y. Omelicheva

Contemporary Politics 22(2): 144-163, 2016

Khalid, A. (2007) Islam after Communism: Religion and Politics in Central Asia (Berkeley, University of California Press).

Layachi, A. (1995) 'Algeria: Reinstating the State or Instating a Civil Society?' in Zartman, I.W (ed.) Collapsed States - The Disintegration and Restoration of Legitimate Authority (Boulder \& London, Lynne Rienner Publishers), pp. 171-189.

Laumulin, M. (2011) 'Islamic Radicalism in Central Asia,” in Warikoo, K. (ed). (Abingdon, UK, Routledge).

Louw, M. (2006) 'Pursuing "Muslimness": Shrines as Sites for Moralities in the Making in PostSoviet Bukhara', Central Asian Survey 25, 3, pp. 319-39.

Mariano, R. (2011) 'The Reciprocal Instrumentalization of Religion and Politics in Brazil,' in Annual Review of the Sociology of Religion, Vol.2 Religion and Politics (Brill), pp. 245266.

Matveeva, A. (2009) 'Legitimising Central Asian Authoritarianism: Political Manipulation and Symbolic Power', Europe-Asia Studies, 61, 7.

McBrien, J. (2006) 'Listening to the Wedding Speaker: Discussing Religion and Culture in Southern Kyrgyzstan', Central Asian Survey, 25, 3, pp. 344.

Nazarbayev, N. (2006) Address of the President of the Republic of Kazakhstan to the People of Kazakhstan, 1 March, available at: http://www.akorda.kz/en/page/page_address-of-thepresident-of-the-republic-of-kazakhstan-nursultan-nazarbayev-to-the-people-ofkazakhstan-march-1-2006 1343986805?print=1

Nazarbayev, N. (2011) Address by President of Kazakhstan at the 38 ${ }^{\text {th }}$ OIC Council of Foreign Ministers, 28 June, available at: http://www.akorda.kz/en/page/address-bypresident-of-kazakhstan-nursultan-nazarbayev-at-the-38th-oic-council-of-foreignministers-astana-june-28-2011_1341926800?print=1

Nazarbayev, N. (2014) 'Kazakhstan's Way - 2050: Common Aim, Common Interests, Common Future', available at: http://www.kazembassyiran.com/english/NewsDet-66-Address-ofthe-President-of-the-Republic-of-Kazakhstan-NNazarbayev-to-the-nation-of-theRepublic-of-Kazakhstan

Naumkin, V. (2005) Radical Islam in Central Asia: Between Pen and Rifle (Rowman \& Littlefield Publishers).

Omelicheva, M. (2011) Counterterrorism Policies in Central Asia (New York, Routeledge).

Omelicheva, M. (2013) 'Central Asian Conceptions of "Democracy": Ideological Resistance to International Democratization', in Vanderhill R. \& Aleprete M.E. Jr. (Lexington Press).

Owen, R. (1992) State, Power and Politics in the Making of Modern Middle East (New York, Routledge).

Pew Research Center (2012) The World's Muslims: Unity and Diversity (Washington, Pew Forum on Religious \& Public Life), available at: http://www.pewforum.org/Muslim/theworlds-muslims-unity-and-diversity.aspx,

Peyrouse, S. (2007) 'Islam in Central Asia: National Specificities and Post-Soviet Globalization', Religion, State and Society 35, 3, pp. 245-60. 
Mariya Y. Omelicheva

Contemporary Politics 22(2): 144-163, 2016

Privratsky, B. (2001) Muslim Turkistan: Kazak Religion and Collective Memory (New York, Routledge).

Radio Free Europe (2015) 'Most Uzbeks Fighting for IS Came from Russia, Theologian Claims', 24 March. Retrieved from LexisNexis Academic.

Rasanayagam, J. (2010) Islam in Post-Soviet Uzbekistan: The Morality of Experience (Cambridge, Cambridge University Press).

Ro'i, Y. \& Wainer, A. (2009) 'Muslim Identity and Islamic Practice in Post-Soviet Central Asia', Central Asian Survey 28, 3, pp. 303-22.

Platteau, J.-P. (2011) 'Political Instrumentalization of Islam and the Risk of Obscurantist Deadlock', World Development 39, 2, pp. 243-60.

Rabinow, P. (ed.) (1991) The Foulcault Reader: An introduction to Foulcault's Thought (London, Penguin).

Siddiqui, H. (1992) 'The Scramble for Central Asia', World Press Review, July, pp. 9-14.

States News Service (2014) 'Kazakh President Slams Islamic State', 22 December. Retrieved from LexisNexis Academic.

Uzbekistan National News Agency (2007) 'President Greets Participants of International Conference "Uzbekistan's Contribution to Development of Islamic Civilization", 14 August. Retrieved from LexisNexis Academic

Weaver, O. (1995) 'Securitization and Desecuritization', in Lipschutz, R. (ed.) (1995).

Yilmaz, I. (2011) 'Beyond Post-Islamism: Transformation of Turkish Islamism Toward "Civil Islam" and Its Potential Influence in the Muslim World', European Journal of Economic and Political Studies, 4, 1, pp. 245-280.

Zürcher, E-J. (2004) 'Islam in the Service of the National and Pre-National State: the Instrumentalisation of Religion for Political Goals by Turkish Regimes between 1990 and 1980', in Turkology Update Leiden Project Working Papers Archive Department of Turkish Studies, Leiden University, pp. 1-5. 
Mariya Y. Omelicheva

Contemporary Politics 22(2): 144-163, 2016

Figure 1. Themes Dominating Official Discourses about Islam in Kazakhstan and Uzbekistan (Frequencies of References)

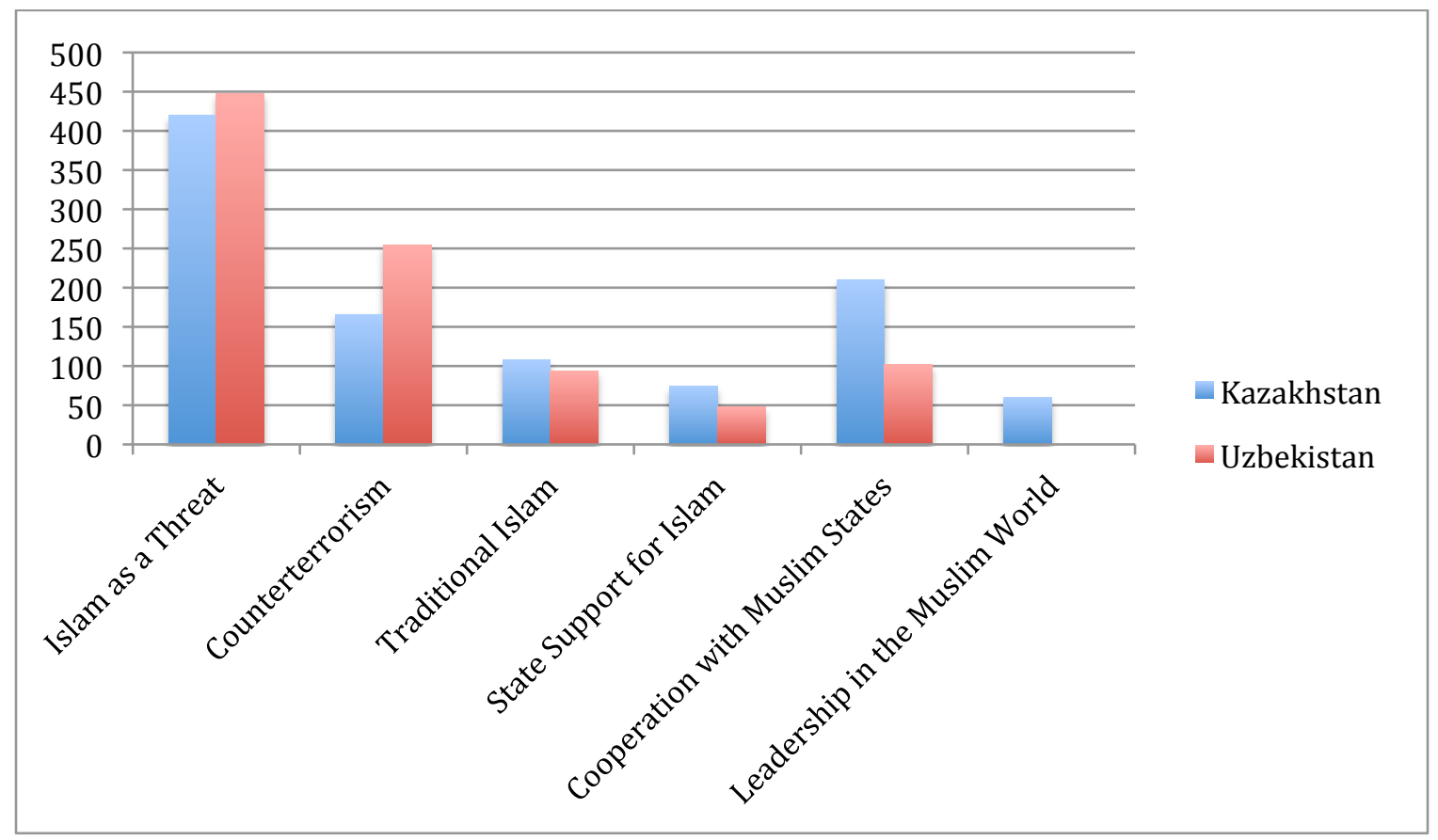


Mariya Y. Omelicheva

Contemporary Politics 22(2): 144-163, 2016

Figure 2. Discursive Representations of Islam and Their Functional Uses

Discursive

presentations

Uses

\begin{tabular}{|c|c|c|c|}
\hline \multicolumn{2}{|c|}{ Instrumentalisation of Islam } \\
\hline Traditional & Official & Radical/Foreign & $\begin{array}{c}\text { Moderate/ } \\
\text { Modern }\end{array}$ \\
\hline $\begin{array}{c}\text { National } \\
\text { unity, } \\
\text { leaders' } \\
\text { nationalist } \\
\text { credentials }\end{array}$ & $\begin{array}{c}\text { Institutionali- } \\
\text { sation of state } \\
\text { control over } \\
\text { religion }\end{array}$ & $\begin{array}{c}\text { Justification of } \\
\text { non-democratic } \\
\text { measures, } \\
\text { stomping } \\
\text { opposition, shifting } \\
\text { responsibility for } \\
\text { regimes' failures }\end{array}$ & $\begin{array}{c}\text { Creating } \\
\text { international } \\
\text { image of } \\
\text { modern and } \\
\text { secular states, } \\
\text { 'waributing to terror' }\end{array}$ \\
\hline \multicolumn{3}{|c|}{ Power Legitimation } \\
\hline
\end{tabular}

